really creating conditions where eventual peace becomes impossible. If you're going to win you have got to live with the consequences."

While some people judge that a "hate campaign" has been in full swing for some time and is, in fact, continuing, Sir Robert has recently stated that "The population [of Vietnam] is gradually losing confidence in the ability of the Viet Cong to win. It is coming in toward the government. The wàr isn't won, but were in the kind of position from which we could win."

There are other experts who would disagree with Mr. Thatcher's judgments. In an interview presented in U.S. News and World Report Raymond Aron, the noted French political scientist, said that "the sort of stability we have had for the last 10,20 or 25 years in the world is based not only on American power but on the American political will to use that power.... Let's asume the advisors to Nixon say, after years of war in Vietnam, 'It was just a mistake-were not interested in Vietnam.' The result would be to lose the credibility of other American commitments. I would donbt that the consequences would be as tremendous as Nixon put them in his November 3 speech, but the consequences would be seriotis and not lightly dismissed."

Raymond Aron also stated that the main condition for minimizing the consequences of an American withdrawal from Vietnam is that "the United States should not impose a coalition government on South Vietnam if such a government is only the camouflage of a Communist takeover."

As in every serious discussion about the war in Vietram, the essential issues emerge from the clash of these differing views. What are the obligations of a great power? Has the U.S. served them well in Vietnam? If not, how can it best correct its position? Has it incurred by the war obligations it did not previously bear? How can the U.S. best discharge its current obligations in fairness to its own people, to Vietnam, and to other countries?

It is inevitable that Americans will continue to differ about the manner and timing of U.S. withdrawal from Vietnam. What is not inevitable, maybe not even probable, but what is certainly possible and desirable is that Americans evaluate Vietnam in terns of our entire foreign policy and American international commitments. We have reached the end of an era and the foreign policy that was designed for it. The dissolution of the war in Vietnam should mean the dissolution of many outdistanced policies and attitudes and the formation of new policies. Those who have been brought into the arena of national politics by Vietnam and have been at least partially educated by it should not themselves plan to withdraw precipitately when that war is ended. They should pose to themselves now the question "After Vietnam-What?"

J.F.

\section{WAR, NEW ATTITUDES TO}

Pope John said that we should undertake our examination of modern war with entirely new attitudes. Whether in response to this adjuration or not, a number of people have attempted to do exactly that. The results are sometimes thoughtful and promising. And sometimes not.

Printed elsewhere in this issue is the major part of a most valuable text recently published by the United Statcs Catholic Conference. The title itself, "The Catholic Conscientious Objector," is one indication of the changes that have taken place within recent years, for not many years ago the Catholic C.O. had to serounge around for isolated texts, historical examples and the help of a handful of elerics if he wanted his draft board to recognize that a man could legitimately be both a Catholic and a C.O. Now, there issues from an official body a statement which not only supports the C.O. but which says that "We should look upon the conscientious objector not as a scandal, but rather as a healthy sign." And this is stated in the context of a just war ethic.

When new attitudes such as these follow from a thoughtfu] examination of the problems, they are most welcome. Unfortunately, much that passes for thoughtful reffection and which appeals to the highest motives is almost scandalous in the basic frivolity of its approach. For example, The Evangelical Church in Germany published late last year a document presenting "theses on the Christian Peace Ethic" which argued thus:

"Since the purpose of military armament today can only be to prevent the outbreak of nuclear warfare, and since 'restricted' wars involve the risk of nucleatr escalation, it is no longer possible for Christian ethics to speak of a "just war' as was still conceivable at the time of the Reformation."

But the purpose of military armament today is no such thing. Yet such foolishness leads on to the conclusion that world justice and peace can be obtained if states abandon the use of military methods to settle conflicts. Such "ifs" have no place in serious discussion and lead to no new attitudes that merit attention. 